\title{
Case Investigations of Infectious Diseases Occurring in Workplaces, United States, 2006-2015
}

\author{
Chia-ping Su, ${ }^{1}$ Marie A. de Perio, Kristin J. Cummings, Anna-Binney McCague, ${ }^{2}$ \\ Sara E. Luckhaupt, Marie Haring Sweeney
}

\begin{abstract}
Workers in specific settings and activities are at increased risk for certain infectious diseases. When an infectious disease case occurs in a worker, investigators need to understand the mechanisms of disease propagation in the workplace. Few publications have explored these factors in the United States; a literature search yielded 66 investigations of infectious disease occurring in US workplaces during 2006-2015. Reported cases appear to be concentrated in specific industries and occupations, especially the healthcare industry, laboratory workers, animal workers, and public service workers. A hierarchy-of-controls approach can help determine how to implement effective preventive measures in workplaces. Consideration of occupational risk factors and control of occupational exposures will help prevent disease transmission in the workplace and protect workers' health.
\end{abstract}

$\mathrm{D}$ espite ongoing efforts to reduce, eliminate, and eradicate infectious diseases, infections continue to pose a global threat to human health. More than 2,000 years ago, Hippocrates noted that "there are many handicrafts and arts which cause those who exercise them certain... plagues" (1). Recent experiences with anthrax, severe acute respiratory syndrome (SARS), influenza A(H1N1), and Ebola virus disease have highlighted the importance of focusing on workplaces not only to identify at-risk populations but also to understand mechanisms of disease propagation and to implement successful control and prevention measures $(2-5)$.

In the United States, work-related infectious diseases are identified in multiple ways. Workers, employers, or workplace health and safety offices may note an unusual case or cluster of disease. Local and state public health de-

Author affiliations: National Institute for Occupational Safety and Health, Cincinnati, Ohio, USA (C.-P. Su, M.A. de Perio,

S.E. Luckhaupt, M.H. Sweeney); Centers for Disease Control and Prevention, Atlanta, Georgia, USA (C.-P. Su, A.-B. McCague); National Institute for Occupational Safety and Health, Morgantown, West Virginia, USA (K.J. Cummings, A.-B. McCague)

DOI: https://doi.org/10.3201/eid2503.180708 partments receive case reports of infectious disease from clinicians and laboratories, and they may conduct investigations, sometimes with assistance from the Centers for Disease Control and Prevention (CDC). CDC's National Institute for Occupational Safety and Health (NIOSH) is the federal public health agency responsible for conducting research and making recommendations to prevent occupational safety and health risks, including work-related infectious diseases. The NIOSH Health Hazard Evaluation (HHE) program responds to requests from workers, employers, and public health agencies and conducts investigations of hazards including infectious diseases that occur in workplaces. Nongovernmental researchers also carry out investigations.

Investigators of work-related infectious disease must consider multiple factors related to the disease, workplace, and workers. Few publications have explored these factors. To illustrate the range of work-related infectious diseases that have been identified in the United States during 20062015 and to benefit future investigations, we examined the peer-reviewed literature and HHE reports on infectious diseases occurring in US workplaces. We describe occupational factors to consider and a systematic approach to control and prevent infectious disease in the workplace. We also note ways that specialized resources may be useful during the course of an investigation.

\section{Literature Review}

\section{Methods}

As defined by the World Health Organization, workrelated diseases may have multiple causes, in which the work environment and other risk factors can play a role (https://www.who.int/occupational_health/activities/

${ }^{1}$ Current affiliation: Taiwan Centers for Disease Control, Taipei, Taiwan, and Institute of Epidemiology and Preventive Medicine, National Taiwan University, Taipei, Taiwan.

${ }^{2}$ Current affiliation: Washington Family Medicine Residency Program, Washington Hospital System, Washington,

Pennsylvania, USA. 
occupational work diseases/en). Work-related infectious diseases can be defined as those primarily caused by occupational exposure to biologic agents. These biologic agents, such as bacteria, fungi, viruses, and parasites, can be transmitted from human to human, from animal to human, or through environmental contact (6). We focused on studies of infectious disease occurring among workers in specific occupational groups or workplaces.

For the literature review, we followed the methods of Haagsma et al. (6). In March 2016, we searched PubMed for articles published since 2006. Our search strategy combined 3 groups of relevant keywords, including case investigation, workers/workplace/occupational, and infectious diseases. We also searched the NIOSH HHE reports database (https://www2a.cdc.gov/hhe/search.asp), using a similar strategy. We classified infectious diseases occurring in workplaces by industry category (work setting), using 2-digit codes of the North American Industry Classification System (NAICS) (https://www.census.gov/ eos/www/naics), and by occupation (type of job). We describe detailed methods of our search of the literature and HHE reports in the Appendix (https://wwwnc.cdc.gov/ EID/article/25/3/18-0708-App1.pdf).

\section{Results}

The literature search yielded 67 articles and 7 HHE reports from 66 investigations of infectious diseases occurring in US workplaces during 2006-2015 (Table 1; Appendix). Cases were concentrated in specific industries and occupations, especially healthcare and work involving contact with animals, reflecting the potential for disease transmission from patients and animals. Complementing previous findings from a systematic review by Haagsma et al. (6), our review of worksite case investigations found that several work-related infectious disease outbreaks or individual cases have been reported among laboratory and public service workers.

Work-related cases were associated with a variety of infectious pathogens. Bacteria were responsible for most reported cases, followed by viruses, fungi, and parasites or protozoa. As noted previously (6), respiratory viruses and zoonotic pathogens still threaten workers' health, especially for healthcare personnel and animalcontact workers. However, we also found reports of some emerging or reemerging pathogens, such as Ebola virus, lymphocytic choriomeningitis virus, norovirus, Bacillus anthracis, and Yersinia pestis, that caused several workplace disease clusters.

\section{Specific Considerations}

Many factors may combine to increase the risk for infection among workers during pathogen transmission. Categories of risk factors for work-related infections include disease factors (such as transmission mode), workplace factors, and worker factors. Considering each of these categories during case investigations is useful in planning and implementing prevention and control strategies.

\section{Disease Factors}

Infectious disease can be transmitted via direct contact (including percutaneous), droplet, airborne (aerosol), vehicles (such as food, water, and fomites), and vectors (Table 2). The studies included in our review suggest that occupations involving interaction with the general population, particularly ill persons, pose an increased risk for infection.

As one example, teachers and public service workers may acquire respiratory virus infections, including influenza and measles, because their work may bring them in contact with persons who are ill (7-10). Workers in the healthcare industry are also at risk for influenza as well as airborne (such as tuberculosis [TB]) and percutaneously transmitted (such as HIV) infection from patients (1113). In 2014, work-related Ebola virus infections among healthcare personnel were a substantial component of the Ebola epidemic worldwide; 2 healthcare personnel acquired Ebola virus disease within the United States $(14,15)$. Occupational contact with human corpses can also result in infectious disease. In 2007, an embalmer in New York, New York, USA, contracted Mycobacterium tuberculosis from a cadaver (16).

Disease transmission patterns are also relevant to those whose work brings them in contact with animals, putting them at risk for zoonotic infections. Occupational exposure to livestock and poultry contributed substantially to work-related infectious diseases. Twenty-nine cases of Campylobacter infection occurred over a period of several years among workers at a poultry processing plant (17), and sealpox virus infections were reported among animal rescue workers in a marine mammal rehabilitation center (18).

Transmission of pathogens in the workplace may occur in 2 directions: workers can acquire infections in the workplace and then also may serve as vectors that spread the disease to others, such as clients and co-workers. We found that workers in food preparation and serving-related occupations have been identified as sources of transmission in foodborne outbreaks. Two delicatessen workers infected with Salmonella from occupational contact with chicken became the source of disease transmission in a 2007 salmonellosis cluster in Minnesota (19). Transmission of norovirus gastroenteritis among workers and customers at a restaurant has also been reported (20). These examples show that preventing workers from acquiring infections in workplaces may also prevent disease transmission among the general public.

Pathogens in the environment can also serve as a source of worker infections through the respiratory route. 
Table 1. Reported case investigations of infectious disease occurring in workplaces, by industry categories, occupations, and diseases, United States, 2006-2015*

\begin{tabular}{|c|c|c|c|}
\hline Industry category (NAICS code) & Occupations & Infectious diseases & References† \\
\hline $\begin{array}{l}\text { Agriculture, forestry, fishing, and } \\
\text { hunting (11) }\end{array}$ & $\begin{array}{l}\text { Hunter } \\
\text { Farmer }\end{array}$ & $\begin{array}{c}\text { Brucellosis } \\
\text { Variant influenza A(H3N2); } \\
\text { Escherichia coli infection }\end{array}$ & $\begin{array}{c}(61) \\
(83) ;(71)\end{array}$ \\
\hline & Rodent breeder & LCMV infection & (82) \\
\hline Construction (23) & Laborer & Coccidioidomycosis & $(23,25)$ \\
\hline Manufacturing (31-33) & $\begin{array}{c}\text { Drum maker } \\
\text { Poultry vaccine production worker } \\
\text { Poultry-processing worker } \\
\text { Furniture company worker } \\
\text { Slaughterhouse inspector } \\
\text { Automobile manufacturing worker }\end{array}$ & $\begin{array}{c}\text { Anthrax } \\
\text { Salmonellosis } \\
\text { Campylobacteriosis } \\
\text { Tuberculosis } \\
\text { Q fever } \\
\text { Legionnaires' disease }\end{array}$ & $\begin{array}{l}(2) \\
(29) \\
(17) \\
(54) \\
(65) \\
(81) \\
\end{array}$ \\
\hline Transportation (48) & Truck driver & $\begin{array}{l}\text { Streptococcus suis infection; } \\
\text { cryptosporidiosis }\end{array}$ & (79); (88) \\
\hline & Pilot, flight attendant & Malaria & (37) \\
\hline $\begin{array}{l}\text { Professional, scientific, and } \\
\text { technical services (54) }\end{array}$ & Laboratory worker & $\begin{array}{c}\text { Vaccinia virus infection, HIV infection, } \\
\text { plague, cowpox, meningococcal } \\
\text { disease, brucellosis }\end{array}$ & $(13,30-35,86)$ \\
\hline $\begin{array}{l}\text { Administrative support and } \\
\text { waste management and } \\
\text { remediation services }(56)\end{array}$ & Landscaper & Tularemia & (21) \\
\hline Education services (61) & School employee, teacher & Influenza & $(8)$ \\
\hline $\begin{array}{l}\text { Healthcare and social } \\
\text { assistance (62) }\end{array}$ & $\begin{array}{l}\text { Healthcare worker (security guard, } \\
\text { nurse, nursing aide, physician, } \\
\text { volunteer, environmental services) }\end{array}$ & $\begin{array}{c}\text { Mumps; MRSA skin infection; } \\
\text { norovirus gastroenteritis; adenovirus } \\
14 \text { infection; RSV infection; } \\
\text { Trichophyton tonsurans skin infection; } \\
\text { meningococcal disease; influenza; } \\
\text { salmonellosis; Ebola virus disease; } \\
\text { measles; TB; } \\
\text { E. coli infection }\end{array}$ & $\begin{array}{l}\text { (51); (52); (56); } \\
\text { (57); (62); (64); } \\
\text { (66); (11,68); } \\
(87) ; \\
(14) ;(92) ; \\
(12,77) \\
(72)\end{array}$ \\
\hline $\begin{array}{l}\text { Arts, entertainment, and } \\
\text { recreation (71) }\end{array}$ & $\begin{array}{c}\text { Wildlife biologist } \\
\text { Animal caretaker } \\
\text { Adult film performer } \\
\text { Spa maintenance worker } \\
\text { Filmmaker } \\
\text { Day camp counselor }\end{array}$ & $\begin{array}{c}\text { Plague } \\
\text { MRSA skin infection } \\
\text { HIV infection } \\
\text { MAC infection } \\
\text { Coccidioidomycosis } \\
\text { Histoplasmosis }\end{array}$ & $\begin{array}{l}(59) \\
(63) \\
(36) \\
(22) \\
(24) \\
(26)\end{array}$ \\
\hline Food services (72) & Cook, food server & $\begin{array}{c}\text { Norovirus gastroenteritis; } \\
\text { salmonellosis; } E \text {. coli infection }\end{array}$ & $\begin{array}{c}(20) ;(19) ; \\
(89)\end{array}$ \\
\hline $\begin{array}{l}\text { Other services except public } \\
\text { administration (81) }\end{array}$ & $\begin{array}{c}\text { Embalmer } \\
\text { Animal refugee worker } \\
\text { Pet store worker } \\
\text { Missionary worker }\end{array}$ & $\begin{array}{c}\text { TB } \\
\text { Tuberculosis; sealpox virus infection } \\
\text { Salmonellosis } \\
\text { Melioidosis; dengue fever }\end{array}$ & $\begin{array}{c}(16) \\
(28) ;(18) \\
(74) \\
(75) ;(70)\end{array}$ \\
\hline Public administration (92) & $\begin{array}{l}\text { US Customs officer } \\
\text { Police officer } \\
\text { Firefighter } \\
\text { Correctional officer }\end{array}$ & $\begin{array}{c}\text { Measles } \\
\text { Meningococcal disease } \\
\text { Cryptosporidiosis } \\
\text { Cryptosporidiosis; Shiga toxin- } \\
\text { producing E. coli infection; TB; } \\
\text { coccidioidomycosis; } \\
\text { Legionellosis; TB }\end{array}$ & $\begin{aligned} &(9,10) \\
&(66) \\
&(88) \\
&(78) ;(71) ;(12) ; \\
&(90) \\
&(73) ;(53)\end{aligned}$ \\
\hline \multicolumn{4}{|c|}{$\begin{array}{l}\text { *An expanded version of this table showing complete details on all cases is available online (https://wwwnc.cdc.gov/EID/article/25/3/18-0708-T1.htm). } \\
\text { HIV, human immunodeficiency virus; LCMV, Iymphocytic choriomeningitis virus; MAC, Mycobacterium avium complex; MRSA, methicillin-resistant } \\
\text { Staphylococcus aureus; RSV, respiratory syncytial virus; TB, tuberculosis. NAICS, } 2012 \text { North American Industry Classification System } \\
\text { (https://www.census.gov/eos/www/naics/). } \\
\text { †Reference numbers >50 and additional details on the literature search are available in the Appendix (https://wwwnc.cdc.gov/EID/article/25/3/18-0708- } \\
\text { App1.pdf). }\end{array}$} \\
\hline
\end{tabular}

A 2006 report described a 21-year-old healthy landscaper diagnosed with tularemia. Traditionally thought of as a zoonotic pathogen, Francisella tularensis can also be acquired via aerosolized bacteria during occupational activities such as lawn mowing and leaf blowing (21). Another report described 2 spa maintenance workers infected with Mycobacterium avium complex organisms, which live in water and are highly resistant to disinfectants, such as chlorine. Occupational exposure to aerosolized bacteria during routine cleaning and maintenance of spa filters and tubs was the likely cause of this outbreak (22).

\section{Workplace Factors}

Regardless of transmission mode, workplace factors can contribute to the propagation of infection. It is crucial to identify aspects of the workplace that pose biologic haz- 
employers or workers are unfamiliar with or unable to comply with the relevant recommendations. For example, CDC staff found 4 malaria cases among employees of a commercial airline who had all traveled to Ghana and stayed at the same hotel before disease onset. None had used antimalarial chemoprophylaxis provided by the company (37). It is unclear why they did not use the chemoprophylaxis, but this cluster underscores the importance of a comprehensive malaria prevention program that includes education and counseling.

\section{Worker Factors}

Individual characteristics, such as impaired immunity, inadequate prophylaxis, and socioeconomic and language factors, may increase the risk for acquisition and transmission of infectious diseases. For example, a case of fatal laboratory-acquired infection caused by $Y$. pestis occurred in a laboratorian in 2009 (32). No additional cases or major deficiencies in engineering controls were identified in this laboratory. A postmortem examination revealed that the affected worker had hereditary hemochromatosis, a condition that increases susceptibility to infection with certain bacterial pathogens. In another situation, Campylobacter infection among poultry-processing workers was found to occur most frequently during the first weeks of work, after which the workers develop immunity that may be protective against future infection (17). Therefore, investigators should consider that individual host susceptibility to certain diseases may play a role in disease transmission in workplaces.

Documented nosocomial transmission puts healthcare personnel at substantial risk for acquiring or transmitting several vaccine-preventable diseases, including hepatitis $\mathrm{B}$, influenza, measles, mumps, rubella, pertussis, and varicella. The Advisory Committee on Immunization Practices and the Hospital Infection Control Practices Advisory Committee recommend that healthcare personnel be vaccinated or have documentation of immunity for all of these diseases; employers must formulate a comprehensive vaccination policy for all healthcare personnel $(38,39)$. Workers in other settings, such as public services, may also be at risk for exposure to vaccine-preventable diseases, such as measles. In 2007, an airport officer contracted measles from an international traveler and may have transmitted it to a second airport worker (9). In 2011, a US Customs and Border Protection officer contracted measles after processing an arriving refugee with measles (10). All of these situations underscore that immunizations should be kept current for workers whose jobs involve frequent contact with the public.

In addition to individual susceptibility and immunity, a worker's socioeconomic status could contribute to risk. Texas officials reported a TB outbreak investigation among workers in a meatpacking plant in 2011. The index case was in a foreign-born patient who had cavitary TB with acid-fast-positive smears. Most of the patient's work contacts were foreign-born. Investigators found that low economic status, limited access to healthcare, and communication and language barriers caused delays in diagnosis and played significant roles in TB transmission among immigrant workers (40).

\section{Approach to Controlling Exposure to Protect Workers}

Investigators of an infectious disease outbreak that is potentially related to a workplace must consider the "who, what, where, when, and why" questions of field epidemiology in the context of a unique and sometimes contentious environment. Stakeholders, including workers, employers, labor unions, trade associations, regulatory agencies, and members of the public, may have distinct and, at times, competing priorities. Barriers to implementing solutions may include those common to all epidemics, such as expense and time constraints, and others more specific to the occupational setting, such as a poorly developed safety culture.

To reduce worker exposure to potential occupational hazards, including biologic agents, we need feasible, effective measures that can be implemented in the workplace. Occupational health and safety specialists have long used the hierarchy of controls (Figure 1) to eliminate or minimize exposure to any occupational hazard. The control methods at the top of the graphic are potentially more effective and protective than those at the bottom. Here are examples of control recommendations made for identified occupational hazards using the hierarchy.

\section{Elimination and Substitution}

Elimination and substitution are the most effective ways to reduce occupational hazards but sometimes can be difficult to implement in an existing work process. For infectious diseases, one should first assess the feasibility of not working in an area in which biohazards are present. If avoidance is not feasible, then decontaminating surfaces, items, and areas in a hazardous workplace can eliminate the possibility of transmission of infectious agents to workers. For environmentally associated laboratory infections, $\mathrm{CDC}$ has published guidance on methods for sterilization and disinfection in laboratories and on the levels of antimicrobial activity associated with liquid chemical germicides (41). However, employers and workers should also be aware of potential health risks when using such disinfectants (42).

Training on early recognition of the key signs and symptoms of common communicable diseases and the 


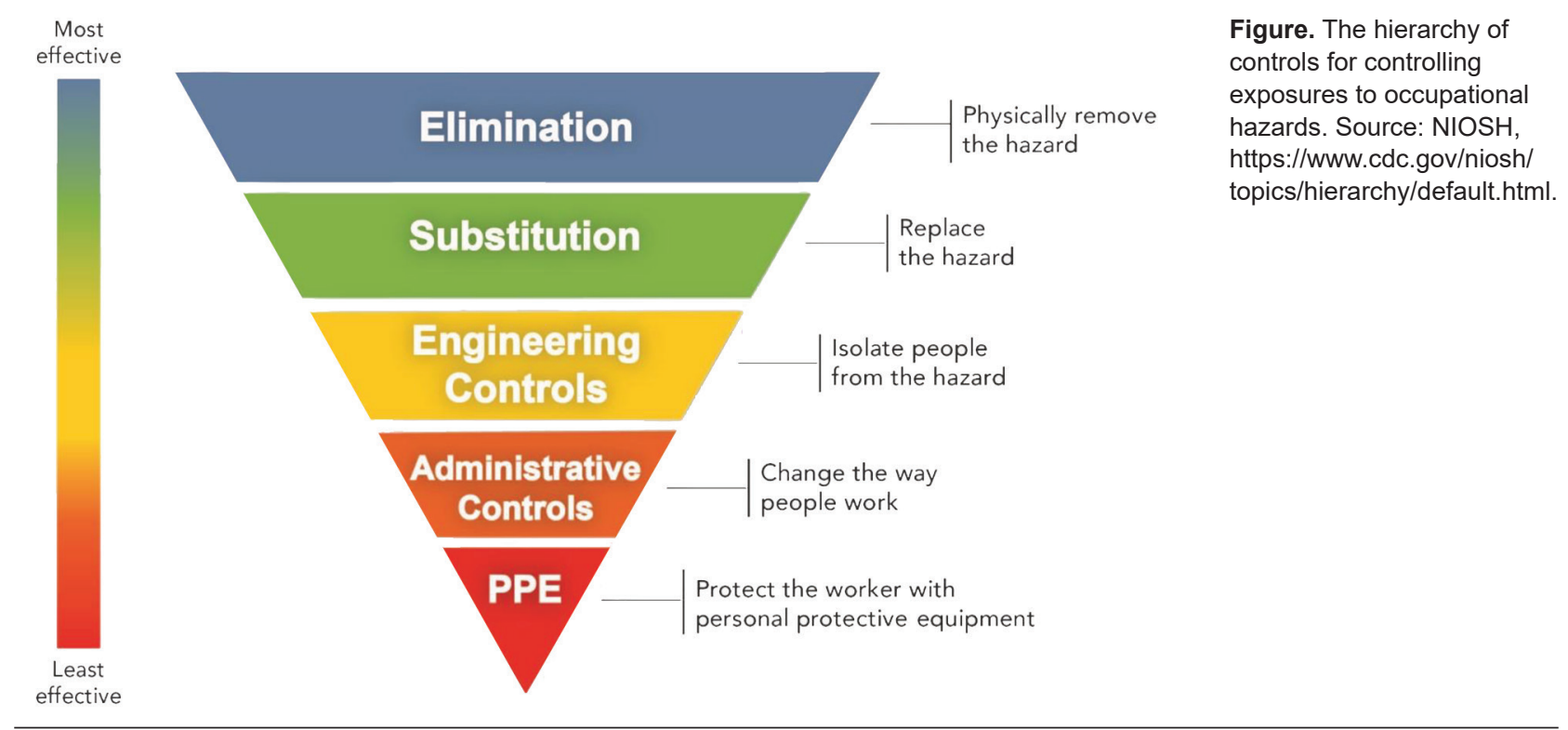

use of sick leave by workers may help to reduce disease transmission in the workplace. For example, CDC guidance for responding to influenza in schools during the 2009 influenza $A(H 1 N 1)$ pandemic included directing students and staff with influenza-like illness to stay home when ill (43). A recent study showed that offering paid sick leave to workers is likely to reduce the spread of disease in workplaces by increasing the rate at which sick workers stay home (44). However, the effectiveness of those measures still needs to be closely evaluated.

\section{Engineering Controls}

Engineering controls in the field of occupational health and safety are physical changes to work processes or equipment to remove hazardous conditions or to place a barrier between workers and hazards. Engineering controls effectively protect workers without placing the primary responsibility of implementation on the worker. Ventilation is by far the most common engineering control, especially for airborne pathogens. Previous modeling data showed that the risk for TB infection in healthcare settings decreases exponentially as room ventilation rates increase (45). Thus, guidelines for preventing transmission of TB in healthcare settings recommend engineering controls such as local exhaust and general ventilation to prevent the spread and reduce the concentration of infectious droplet nuclei in the air. Supplementing ventilation systems with high-efficiency particulate air filtration, ultraviolet germicidal irradiation, or both can further enhance system performance and reduce the spread of airborne disease (46).

Nonventilation engineering controls also can reduce or eliminate pathogen exposure in the workplace. For example, dust suppression during construction, including continuous soil-wetting and proper covering, could decrease the risk for coccidioidomycosis among outdoor workers (23). In addition, evidence shows that engineering controls can reduce healthcare personnel's exposure to bloodborne pathogens. Safety needle devices with built-in engineering controls reduce the risk for needlestick injury among healthcare personnel (47).

\section{Administrative Controls}

Administrative controls are methods such as standard operating procedures that change the way work is performed. Their effectiveness depends on the availability of the control, employer commitment, and worker acceptance. Regular monitoring and reinforcement are necessary to ensure that workers follow policies and procedures consistently. The CDC publication Biosafety in Microbiological and Biomedical Laboratories addresses recommended practices for working safely from a biosafety perspective (41).

Developing and implementing a mandated workplace health regulation can be an effective administrative control. In December 1991, mandatory hepatitis B vaccination of all healthcare personnel (at employers' expense) became a federal standard under the Occupational Safety and Health Act (48). The regulation accelerated the use of hepatitis B vaccine for healthcare personnel. As the result of routine vaccination and improved infection control precautions, the number of hepatitis B virus infections among healthcare personnel decreased from $\approx 10,000$ in 1982 to $\approx 304$ in 2004 (39). In addition, administrative measures of TB control, such as developing and implementing a written TB infection-control plan, prevent disease transmission in healthcare settings (46). 


\section{Personal Protective Equipment}

Various types of personal protective equipment (PPE) are available to minimize exposure to hazards in workplaces. PPE, such as respirators, gloves, goggles, and coveralls, provides a physical barrier between the worker and the infectious agent. Compared with other methods of controlling exposure, PPE is the least effective but probably best-known method used for infectious disease prevention. Proper use of PPE requires a comprehensive program and a high level of worker involvement and commitment. When engineering, work practice, and administrative controls are not feasible or do not provide sufficient protection, PPE may be the only reliable method of disease prevention for workers. Therefore, employers must provide their workers with PPE that is appropriate to the task and the correct size for the user, along with proper training on use and on donning and doffing methods.

In the early stages of epidemics of emerging infectious diseases, such as Ebola virus disease, lack or misuse of PPE can lead to infections in healthcare personnel. In 2014, the transmission of Ebola virus to 2 nurses who provided care to an Ebola-infected patient at a US hospital revealed the importance of directive PPE recommendations and standardized training efforts for healthcare personnel. Interventions included a system of trained observers supervising the donning and doffing of PPE $(5,49)$. Even though the quality of evidence is low, the risk for contamination may be reduced by double-gloving, following directives for donning and doffing procedures, and instituting more active training (50).

\section{Additional Resources}

The NIOSH Surveillance Program works with partners at CDC and the Council of State and Territorial Epidemiologists to promote inclusion of standard occupational information in the National Notifiable Disease Surveillance system (in which most conditions included are infectious) and in electronic medical records, to facilitate detection of possible disease transmission in workplaces (https://www.cdc.gov/niosh/topics/ehr/ default.html). Once a disease cluster or outbreak is suspected, the NIOSH HHE program can be a resource for technical assistance and consultation during the case investigation in a workplace. Workers, employers, or public health professionals can request an evaluation of health hazards in the workplace (https://www.cdc.gov/ niosh/hhe). NIOSH makes recommendations aimed at controlling the hazard; these are voluntary but can reduce risk and improve the health and safety of the workforce.

\section{Conclusions}

We found that cases of work-related infectious diseases in the United States during 2006-2015 appeared to be concentrated in specific industries and occupations, especially in healthcare and among laboratory, animal, and public service workers. The biosafety programs in these industries could be strengthened. Case investigations of infectious disease occurring in a workplace can be challenging with regard to linking the symptoms of a disease to a specific pathogen or exposure source and identifying effective preventive strategies. A multidisciplinary approach that includes epidemiologists, physicians, industrial hygienists, and engineers may be beneficial.

Emerging and reemerging work-related infectious diseases will continue to threaten workers' health. Previously published literature has identified several highrisk occupations, but other occupations may also be at risk. Indeed, we cannot know with certainty which industry or which workers will be at risk in the future. Considering occupational risk factors and controlling exposures among workers when investigating infectious disease may help prevent disease transmission in the workplace. In addition, because person-to-person transmission between workers and members of the public can propagate some disease outbreaks, assessment of worker infection may contribute to control of disease outbreaks in communities.

\section{Acknowledgments}

We thank Onnalee A. Gomez, Seleen S. Collins, and Stephen Martin for their technical assistance and consultation. We also highly appreciate the comments and suggestions of Derry Stover and Kenneth Rosenman on an earlier version of this paper.

\section{About the Author}

Dr. Su was an Epidemic Intelligence Service officer at the CDC's National Institute for Occupational Safety and Health at the time of the study. He is now a medical officer and infectious diseases physician at the Field Epidemiology Training Program at the Taiwan Centers for Disease Control in Taipei. His primary research interests include outbreak investigation and all infectious diseases of public health importance, especially influenza, emerging infectious diseases, and infectious diseases that occur in the workplace.

\section{References}

1. Price GM. Medicine and the industries. Bulletin of the American Academy of Medicine. 1917;18:134-9.

2. Centers for Disease Control and Prevention (CDC). Cutaneous anthrax associated with drum making using goat hides from West Africa-Connecticut, 2007. MMWR Morb Mortal Wkly Rep. 2008;57:628-31.

3. Fowler RA, Lapinsky SE, Hallett D, Detsky AS, Sibbald WJ, Slutsky AS, et al.; Toronto SARS Critical Care Group. Critically ill patients with severe acute respiratory syndrome. JAMA. 2003;290:367-73. http://dx.doi.org/10.1001/jama.290.3.367

4. Suarthana E, McFadden JD, Laney AS, Kreiss K, Anderson HA, Hunt DC, et al. Occupational distribution of persons with confirmed 2009 H1N1 influenza. J Occup Environ Med. 2010;52:1212-6. http://dx.doi.org/10.1097/JOM.0b013e3181fd32e4 
5. Cummings KJ, Choi MJ, Esswein EJ, de Perio MA, Harney JM, Chung WM, et al. Addressing infection prevention and control in the first U.S. community hospital to care for patients with Ebola virus disease: context for national recommendations and future strategies. Ann Intern Med. 2016;165:41-9. http://dx.doi.org/ 10.7326/M15-2944

6. Haagsma JA, Tariq L, Heederik DJ, Havelaar AH. Infectious disease risks associated with occupational exposure: a systematic review of the literature. Occup Environ Med. 2012;69:140-6. http://dx.doi.org/10.1136/oemed-2011-100068

7. Lessler J, Reich NG, Cummings DA. New York City Department of Health and Mental Hygiene Swine Influenza Investigation Team. Outbreak of 2009 pandemic influenza A(H1N1) at a New York City school. N Engl J Med. 2009;361:2628-36.

8. Centers for Disease Control and Prevention (CDC). Outbreak of 2009 pandemic influenza A (H1N1) at a school-Hawaii, May 2009. MMWR Morb Mortal Wkly Rep. 2010;58:1440-4.

9. Chen TH, Kutty P, Lowe LE, Hunt EA, Blostein J, Espinoza R, et al. Measles outbreak associated with an international youth sporting event in the United States, 2007. Pediatr Infect Dis J. 2010;29:794-800. http://dx.doi.org/10.1097/INF.0b013e3181dbaacf

10. Centers for Disease Control and Prevention (CDC). Measles outbreak associated with an arriving refugee- Los Angeles County, California, August-September 2011. MMWR Morb Mortal Wkly Rep. 2012;61:385-9.

11. Magill SS, Black SR, Wise ME, Kallen AJ, Lee SJ, Gardner T, et al. Investigation of an outbreak of 2009 pandemic influenza A virus (H1N1) infections among healthcare personnel in a Chicago hospital. Infect Control Hosp Epidemiol. 2011;32:611-5. http://dx.doi.org/10.1086/660097

12. Medrano BA, Salinas G, Sanchez C, Miramontes R, Restrepo BI, Haddad MB, et al. A missed tuberculosis diagnosis resulting in hospital transmission. Infect Control Hosp Epidemiol. 2014;35:534-7. http://dx.doi.org/10.1086/675833

13. Joyce MP, Kuhar D, Brooks JT. Notes from the field: occupationally acquired HIV infection among health care workers-United States, 1985-2013. MMWR Morb Mortal Wkly Rep. 2015;63:1245-6.

14. Chevalier MS, Chung W, Smith J, Weil LM, Hughes SM, Joyner SN, et al.; Centers for Disease Control and Prevention (CDC). Ebola virus disease cluster in the United States-Dallas County, Texas, 2014. MMWR Morb Mortal Wkly Rep. 2014;63:1087-8.

15. Yacisin K, Balter S, Fine A, Weiss D, Ackelsberg J, Prezant D, et al.; Centers for Disease Control and Prevention (CDC). Ebola virus disease in a humanitarian aid worker-New York City, October 2014. MMWR Morb Mortal Wkly Rep. 2015;64:321-3.

16. Anderson JA, Meissner JS, Ahuja SD, Shashkina E, O'Flaherty T, Proops DC. Confirming Mycobacterium tuberculosis transmission from a cadaver to an embalmer using molecular epidemiology. Am J Infect Control. 2015;43:543-5. http://dx.doi.org/10.1016/ j.ajic.2015.01.027

17. de Perio MA, Niemeier RT, Levine SJ, Gruszynski K, Gibbins JD. Campylobacter infection in poultry-processing workers, Virginia, USA, 2008-2011. Emerg Infect Dis. 2013; 19:286-8. http://dx.doi.org/10.3201/eid1902.121147

18. Roess AA, Levine RS, Barth L, Monroe BP, Carroll DS, Damon IK, et al. Sealpox virus in marine mammal rehabilitation facilities, North America, 2007-2009. Emerg Infect Dis. 2011;17:2203-8. http://dx.doi.org/10.3201/eid1712.101945

19. Hedican E, Miller B, Ziemer B, LeMaster P, Jawahir S, Leano F, et al. Salmonellosis outbreak due to chicken contact leading to a foodborne outbreak associated with infected delicatessen workers. Foodborne Pathog Dis. 2010;7:995-7. http://dx.doi.org/10.1089/ fpd.2009.0495

20. Centers for Disease Control and Prevention (CDC). Norovirus outbreak associated with ill food-service workers-Michigan,
January-February 2006. MMWR Morb Mortal Wkly Rep. 2007;56:1212-6.

21. Hofinger DM, Cardona L, Mertz GJ, Davis LE. Tularemic meningitis in the United States. Arch Neurol. 2009;66:523-7. http://dx.doi.org/10.1001/archneurol.2009.14

22. Moraga-McHaley SA, Landen M, Krapfl H, Sewell CM. Hypersensitivity pneumonitis with Mycobacterium avium complex among spa workers. Int J Occup Environ Health. 2013;19:55-61. http://dx.doi.org/10.1179/2049396712Y.0000000015

23. Cummings KC, McDowell A, Wheeler C, McNary J, Das R, Vugia DJ, et al. Point-source outbreak of coccidioidomycosis in construction workers. Epidemiol Infect. 2010;138:507-11. http://dx.doi.org/10.1017/S0950268809990999

24. Wilken JA, Marquez P, Terashita D, McNary J, Windham G, Materna B; Centers for Disease Control and Prevention.

Coccidioidomycosis among cast and crew members at an outdoor television filming event-California, 2012. MMWR Morb Mortal Wkly Rep. 2014;63:321-4.

25. Wilken JA, Sondermeyer G, Shusterman D, McNary J, Vugia DJ, McDowell A, et al. Coccidioidomycosis among workers constructing solar power farms, California, USA, 2011-2014. Emerg Infect Dis. 2015;21:1997-2005. http://dx.doi.org/10.3201/ eid2111.150129

26. Centers for Disease Control and Prevention. Notes from the field: histoplasmosis outbreak among day camp attendees-Nebraska, June 2012. MMWR Morb Mortal Wkly Rep. 2012;21:747-8.

27. Davidow AL, Mangura BT, Wolman MS, Bur S, Reves R, Thompson V, et al. Workplace contact investigations in the United States. Int J Tuberc Lung Dis. 2003;7(Suppl 3):S446-52.

28. Murphree R, Warkentin JV, Dunn JR, Schaffner W, Jones TF. Elephant-to-human transmission of tuberculosis, 2009. Emerg Infect Dis. 2011;17:366-71. http://dx.doi.org/10.3201/ eid1703.101668

29. Centers for Disease Control and Prevention. Salmonella serotype enteritidis infections among workers producing poultry vaccineMaine, November-December 2006. MMWR Morb Mortal Wkly Rep. 2007;56:877-9.

30. Centers for Disease Control and Prevention. Laboratory-acquired vaccinia exposures and infections - United States, 2005-2007. MMWR Morb Mortal Wkly Rep. 2008;57:401-4.

31. Centers for Disease Control and Prevention. Laboratory-acquired vaccinia virus infection-Virginia, 2008. MMWR Morb Mortal Wkly Rep. 2009;58:797-800.

32. Centers for Disease Control and Prevention. Fatal laboratoryacquired infection with an attenuated Yersinia pestis strainChicago, Illinois, 2009. MMWR Morb Mortal Wkly Rep. 2011;60:201-5.

33. McCollum AM, Austin C, Nawrocki J, Howland J, Pryde J, Vaid A, et al. Investigation of the first laboratory-acquired human cowpox virus infection in the United States. J Infect Dis. 2012;206:63-8. http://dx.doi.org/10.1093/infdis/jis302

34. Traxler RM, Guerra MA, Morrow MG, Haupt T, Morrison J, Saah JR, et al. Review of brucellosis cases from laboratory exposures in the United States in 2008 to 2011 and improved strategies for disease prevention. J Clin Microbiol. 2013;51:31326. http://dx.doi.org/10.1128/JCM.00813-13

35. Sheets CD, Harriman K, Zipprich J, Louie JK, Probert WS, Horowitz M, et al. Fatal meningococcal disease in a laboratory worker-California, 2012. MMWR Morb Mortal Wkly Rep. 2014;63:770-2.

36. Wilken JA, Ried C, Rickett P, Arno JN, Mendez Y, Harrison RJ, et al. Occupational HIV transmission among male adult film performers - multiple states, 2014. MMWR Morb Mortal Wkly Rep. 2016;65:110-4. http://dx.doi.org/10.15585/mmwr.mm6505a3

37. Centers for Disease Control and Prevention. Notes from the field: malaria imported from West Africa by flight crews - Florida 
and Pennsylvania, 2010. MMWR Morb Mortal Wkly Rep. 2010;59:1412.

38. Bolyard EA, Tablan OC, Williams WW, Pearson ML,

Shapiro CN, Deitchman SD; Hospital Infection Control Practices Advisory Committee. Guideline for infection control in healthcare personnel, 1998. Infect Control Hosp Epidemiol. 1998;19:407-63. http://dx.doi.org/10.2307/30142429

39. Advisory Committee on Immunization Practices; Centers for Disease Control and Prevention. Immunization of healthcare personnel: recommendations of the Advisory Committee on Immunization Practices (ACIP). MMWR Recomm Rep. 2011;60(RR-7):1-45.

40. Kambali S, Nantsupawat N, Lee M, Nugent K. A workplace tuberculosis case investigation in the presence of immigrant contacts from high prevalence countries. J Community Health. 2015;40:576-80. http://dx.doi.org/10.1007/s10900-014-9946-3

41. CDC. Biosafety in microbiological and biomedical laboratories (BMBL), 5th edition [cited 2017 May 4]. https://www.cdc.gov/ biosafety/publications/bmbl5

42. Quinn MM, Henneberger PK, Braun B, Delclos GL, Fagan K, Huang V, et al.; National Institute for Occupational Safety and Health (NIOSH), National Occupational Research Agenda (NORA) Cleaning and Disinfecting in Healthcare Working Group. Cleaning and disinfecting environmental surfaces in health care: Toward an integrated framework for infection and occupational illness prevention. Am J Infect Control. 2015; 43:424-34. http://dx.doi.org/10.1016/j.ajic.2015.01.029

43. Centers for Disease Control and Prevention. CDC guidance for state and local public health officials and school administrators for school (K-12) responses to influenza during the 2009-2010 school year [cited 2017 May 4]. https://www.cdc.gov/h1n1flu/schools/ schoolguidance.htm

44. Piper K, Youk A, James AE III, Kumar S. Paid sick days and stay-at-home behavior for influenza. PLoS One. 2017;12:e0170698. http://dx.doi.org/10.1371/journal.pone.0170698

45. Fennelly KP, Nardell EA. The relative efficacy of respirators and room ventilation in preventing occupational tuberculosis. Infect Control Hosp Epidemiol. 1998;19:754-9. http://dx.doi.org/ $10.2307 / 30141420$

46. Jensen PA, Lambert LA, Iademarco MF, Ridzon R; CDC. Guidelines for preventing the transmission of Mycobacterium tuberculosis in health-care settings, 2005. MMWR Recomm Rep. 2005;54(RR-17):1-141.

47. Ballout RA, Diab B, Harb AC, Tarabay R, Khamassi S, Akl EA. Use of safety-engineered devices by healthcare workers for intravenous and/or phlebotomy procedures in healthcare settings: a systematic review and meta-analysis. BMC Health Serv Res. 2016;16:458. http://dx.doi.org/10.1186/ s12913-016-1705-y

48. Bloodborne pathogens: the standard, 29 C.F.R. Sect. 1910.1030 (1991).

49. Hageman JC, Hazim C, Wilson K, Malpiedi P, Gupta N, Bennett $\mathrm{S}$, et al. Infection prevention and control for Ebola in health care settings-West Africa and United States. MMWR Suppl. 2016;65:50-6. http://dx.doi.org/10.15585/ mmwr.su6503a8

50. Verbeek JH, Ijaz S, Mischke C, Ruotsalainen JH, Mäkelä E, Neuvonen K, et al. Personal protective equipment for preventing highly infectious diseases due to exposure to contaminated body fluids in healthcare staff. Cochrane Database Syst Rev. 2016;4:CD011621.

Address for correspondence: Sara E. Luckhaupt, Centers for Disease Control and Prevention, 1090 Tusculum Ave, Mailstop R-17, Cincinnati, OH 45226, USA; email: sluckhaupt@cdc.gov

\section{EID Podcast:}

\section{A Tale of Two}

Kitchens, Meals,

and Microbes

Byron Breedlove and Martin I. Meltzer

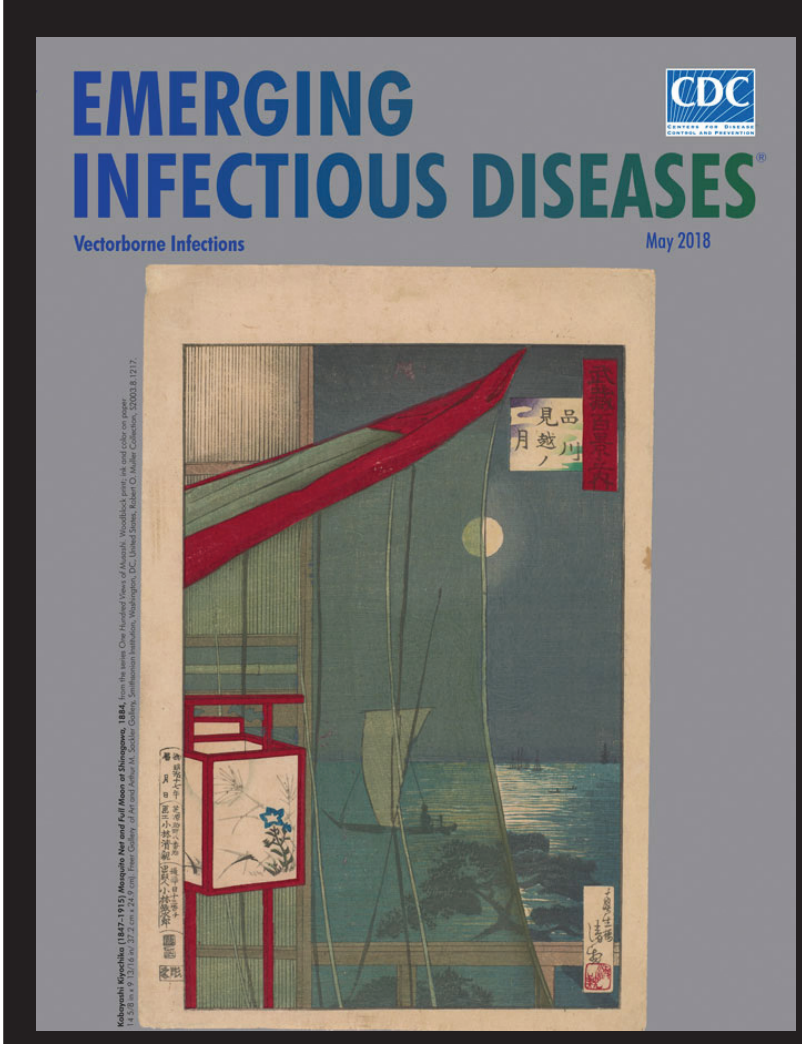

Visit our website to listen: https://wwwnc.cdc.gov/eid/ article/24/6/ac-2406_article

EMERGING INFECTIOUS DISEASES 